\title{
Notaries of Color in Colonial Panama: Limpieza de Sangre, Legislation, and Imperial Practices in the Administration of the Spanish Empire
}

$\mathrm{O}$ n July 20, 1740, King Philip V of Spain was given paperwork regarding a dispute over the adjudication of a notarial office in Panama City and, as usual, he was expected to make a decision. ${ }^{1}$ The king also had in hand recommendations from the Cámara of the Consejo de Indias. The king would have handled the case in a relatively straightforward manner, but for one fact-the two notaries involved in the public bid were of African descent.

The notarial office (escribano público y del número) in question had been auctioned to Francisco Garcia y Robles, a white notary, for 1,525 pesos. ${ }^{2}$ A man named Jorge Geronimo Perez had also bid for it but lost, and was appealing the auction results on the grounds that the former owner of the notarial office

I would like to thank Diana Paton and Keith Brewster for reading and providing suggestions on very initial versions of this text, and Jean-Sébastien Balzat for reading the latest version. Reviewers for The Americas, both the anonymous reviewer and Ann Twinam, provided invaluable criticism and commentary. The discussion with Twinam and my reading of Chapter 5 of her forthcoming book from Stanford University Press, provisionally titled Erasing "American Defects," [cited herein as "Twinam, forthcoming"] has proved fruitful and enlightening. Funding from the Federation of Women Graduates Charitable Foundation, the AHRC Doctoral Award, and the Society for Latin American Studies Post-doctoral Travel Grant (UK) made possible the archival research.

1. King Felipe V, San Ildefonso, July 20, 1740. Archivo General de Indias, Gobierno, Audiencia de Panamá, leg. 119 [hereafter AGI, Panamá]. I quote personal names as they appear in the primary sources, without modernizing or correcting them, thus Joseph instead of José, Gomez instead of Gómez, and the like.

2. I have opted to translate escribano público as 'notary (public),' following the work of Lockhart and Burns. James Lockhart, Spanish Peru, 1532-1560: A Colonial Society (Madison: University of Wisconsin Press, 1968), p. 68; Kathryn Burns, Into the Archive: Writing and Power in Colonial Peru (Durham: Duke University Press, 2010), glossary on pp. 205-206. Other authors have preferred 'scribe,' but this term does not necessarily encompass a knowledge of legal formulas or terminology. See for example Michael Scardaville, "Justice by Paperwork: A Day in the Life of a Court Scribe in Bourbon Mexico City," Journal of Social History 36:4 (Summer 2003), pp. 979-1007. However, the present article does not deal with notarios (ecclesiastical notaries). Jorge Luján Muñoz, Los escribanos en las Indias Occidentales, y en particular en el Reino de Guatemala (Guatemala: Instituto Guatemalteco de Derecho, [1964] 1977), pp. 14-15. 
had handed it over to him when the latter resigned. In addition, Perez argued, his long career in notarial service, including a time as assistant in the office of a notary, demonstrated his suitability for the post. To better assess his claim, the local authorities had required Perez to present documentation of his fiat (title of notary) and the dispensation of his defecto (defect), a document that stated he was of African descent-his grandmother was a mulata. However, Perez did not comply, and the case was forwarded to Spain. There, the Cámara and the king encountered a complication: the notary who had certified the auction was Joseph de Avellaneda, himself of African descent. To resolve the conflict, Philip issued a decree requesting that the two notaries of color present their fiats and dispensas de color o calidad (dispensations of color or calidad), both issued by the king, to the audiencia of Panama. ${ }^{3}$ If either refused to obey, he would be prevented from continuing to exercise his occupation. The decree also stated that the audiencia should not allow any mestizo or mulato to use the title of notary unless the king had provided him with an exemption for his defecto. ${ }^{4}$

This case highlights the existence of a seemingly contradictory reality. Although official imperial legislation prohibited notary positions to people of African descent, the monarchs and the Consejo de Indias - and not so infrequentlygranted them individual dispensas to work as notaries and to own notarial offices. The case before Philip V did not represent an isolated incident. I have identified 42 individuals of African descent who worked as notaries in Panama between the early seventeenth century and the 1810s, and frequently they owned notarial offices as well. ${ }^{5}$ These 42 cases demonstrate the existence of an imperial practice that started with the Habsburg monarchs and developed under the Bourbons. I argue that this practice needs to be understood within Spain's policy of flexible legislation, which allowed for adaptations to maintain its empire. It evidences an accommodative approach on the part of metropolitan authorities to the changing social reality in the Spanish-American colonies. The

3. As evidence of the occasional use of dispensa 'de calidad' instead of 'de color,' see note 83 .

4. King Felipe V, San Ildefonso, July 20, 1740, AGI, Panamá, 119. All remaining translations are mine.

5. This is the first article to study notaries of color in Panama systematically, although they have also been analyzed by Alfredo Castillero Calvo, "Color y movilidad social," in Historia General de Panamá, Castillero Calvo, ed. (Panama: Comité Nacional del Centenario de la República, 2004), vol. 1-1, pp. 303306; ibid., "Los negros y mulatos libres en la historia social panameña," Lotería 164 (July 1969), pp. 86-88; ibid., Los negros y mulatos libres en la historia social panameña (Panama: Comisión de Estudios Interdisciplinarios para el Desarrollo de la Nacionalidad, 1969), pp. 28-30; Argelia María Tello de Ugarte, "Panama en la segunda mitad del s. XVIII. Factores de unión y separación con el virreinato de Nueva Granada" (Ph.D. diss., Universidad Complutense de Madrid, 1977), pp. 216-217; Samuel Alberola, "Panamà au XVIIIème siècle (1739-1810): évolution économique et sociale d'une zone strategique de l'Empire Espagnol" (Ph.D. diss., École Pratique des Hautes Études-Université de Paris X, 1975), p. 279; and Aida M. Pérez Calderón, "Política y sociedad en Panamá en la primera mitad del s. XVIII" (Ph.D. diss., Universidad Complutense de Madrid, 1985), pp. 271-275. 
practice would ultimately be made official with the late-eighteenth century gracias al sacar decrees.

In undertaking a quantitative and qualitative analysis of notaries of African descent in Panama over two centuries, this article engages with and contributes to four main lines of research in early-modern Latin American history: the role of notaries, the importance of limpieza de sangre and calidad in Spanish America, the workings of the administration of the Spanish territories, and the experience of free people of African descent. In my analysis, I question the predominant historiography that supports the notion that notaries were of Spanish descent, and maintains that African descendants were allowed to become notaries only through a combination of the crown's economic need and a lack of interest in the occupation on the part of whites or Spaniards. I also question the suggestion that this permission was granted in significant numbers only in moments of crisis, or when there were difficulties in finding suitable candidates to occupy the posts, mostly from the early eighteenth century onward. The research I present here clearly establishes that people of color became notaries from the early seventeenth century. Even though greater public revenue might have been increasingly important in the late early-modern period, it is clear from re-analysis of the documentation and the incorporation of new material that there was no major turning point in the eighteenth century based on the above-mentioned factors. The growth in the number of notaries of African descent happened over time and was due to different factors.

In the earliest appointments, an African descendant would most likely have had his defecto dispensed as a gratuitous personal gracia (favor). Over time, however, some began paying a fee for an appointment, which ultimately led to the monetary exchange associated with the gracias al sacar. Ann Twinam has very recently argued that Panamanian notaries, along with Cuban surgeons, can be documented as mid-eighteenth century benchmarks for what by the end of the century became the gracias al sacar, and she has identified the first payment of a fee for that gracia or dispensa in the early 1760s. ${ }^{6}$ However, I have been able to trace an approximate evolution of the dispensa in the notes of some fiscales and thus show that the paths of these 42 men demonstrate a much earlier and far-reaching practice that provides hints for understanding local and imperial perceptions of calidad.

There has been much discussion of the meaning of calidad in historiography, and we now understand that its meaning went far beyond simple ancestry to embrace a combination of distinguishing factors: origins, reputation, public 
standing, economic means, networks, etc. ${ }^{7}$ While a dispensa de color can be understood literally as an intent to dispense with an aspirant's African origins, the fact that such a dispensation was granted meant that this notary was accepted as a peer, and that he had many of the other elements that made up a person's calidad: he was wealthy enough to pay for the fiat, notarial office, and frequently a dispensation; was literate, properly trained for the office, and well-connected locally; and displayed proper or accepted social behavior. Given that the dispensations eventually constituted-as we now know-a precedent for the gracias al sacar, one could argue that notaries of color were aiming at whitening their lineage or passing as something other than persons of African descent. However, I propose that the unofficial practice of granting dispensations, well-known locally and sanctioned officially in spite of existing legislation, meant that African ancestry was not perceived as an impediment by aspirants and their parents. Very likely, they did not aim to obliterate what was labeled as a defecto, but to have it set aside by means of a dispensa. In other words, they recognized and accepted their African ancestry in the majority of cases. This may have been something "safe to claim" in the Panamanian notarial context, in the same way Ben Vinson has argued it was safe to claim African ancestry among the colored militia in Mexico. ${ }^{8}$ In Mexico, participation in the militia gave men of color recognition and a set of benefits under circumstances in which their ancestry was not an impediment, but the requirement. In the Panamanian case, African ancestry ceased over time to be an impediment to a notarial aspirant but simply an aspect for which, in most cases, such a person could receive a dispensa. Many of these men had no real need to hide their ancestry and some even declared it, although none of the documentation they presented to support their applications overtly stated it, a theme to which I return below. I propose that the practice of granting dispensas, extending as it did over two centuries, facilitated the formation of what could be called a small bureaucratic elite of African descent in Panama.

Through discussion of the dispensa and reassessment of historiographical assumptions regarding the importance of limpieza de sangre and legitimate birth in gaining access to the lower Spanish American bureaucratic ranks, this article takes further our understanding of the meanings of calidad in different

7. See among others Patricia Seed, "Social Dimensions of Race: Mexico City, 1753," Hispanic American Historical Review 64:2 (November 1982), p. 574; Ben Vinson III, Bearing Arms for His Majesty. The FreeColored Militia in Colonial Mexico (Stanford: Stanford University Press, 2001), p. 4; Jane E. Mangan, "A Market of Identities: Women, Trade, and Ethnic Labels in Colonial Potosí," in Imperial Subjects: Race and Identity in Colonial Latin America, Andrew Fisher and Matthew D. O'Hara, eds. (Durham and London: Duke University Press, 2009), p. 63 and p. 78 note 5; and María Elena Martínez, Genealogical Fictions. Limpieza de Sangre, Religion, and Gender in Colonial Mexico (Stanford: Stanford University Press, 2008).

8. Vinson, Bearing Arms, chapt. 3 and pp. 226-227. 
social and legal spheres. Analysis of the social networks of this subset of free men of color, and their individual strategies of achieving upward social mobility, allow to reassess our understanding of Panama's colonial society, and the ways in which people of African descent achieved social and economic success and held occupations of responsibility and respectability.

\section{Becoming a Notary in Early Modern Spanish America}

Spanish American notaries have received a great deal of attention in recent historiography. ${ }^{9}$ We now have a firm understanding of the path a man had to follow to become a notary, and have learned that it was similar to that of any other craft. The child was apprenticed to a master, the owner of a notarial office, at an early age (between 9 and 12 years old), and worked in the notary's office while studying law, formulas, and authors. ${ }^{10}$ Once his apprenticeship was completed, he could become an oficial in the office of a notary and from that base develop his career, slowly rising up through the internal hierarchy to become oficial mayor (head assistant). ${ }^{11}$ Alternatively, he could attempt to obtain a fiat and then buy a notarial office. ${ }^{12}$ To obtain the fiat, the candidate had to petition the Consejo de Indias and the king, providing evidence of experience, ability, origin (limpieza), and age (at least 25 years old). ${ }^{13}$ If the petition demonstrated that the aspirant met all of the requirements, the Cámara would grant the fiat upon examination by local authorities. ${ }^{14}$ Then, the notary could participate in an auction to buy a notarial office whenever one

9. See Burns, Into the Archive; ibid., "Notaries, Truth, and Consequences," American Historical Review 110:2 (April 2005), pp. 350-379; ibid., "Making Indigenous Archives: The Quilcaycamayoc of Colonial Cuzco," Hispanic American Historical Review 91:4 (November 2011), pp. 665-689; Lockhart, Spanish Peru, pp. 68-76; Scardaville, "Justice by Paperwork"; Tamar Herzog, Mediación, archivos y ejercicio: los escribanos de Quito (siglo XVII) (Frankfurt: Vittorio Klostermann, 1996); Juan Ricardo Jiménez Gómez, Un formulario notarial mexicano del siglo XVIII: la instrucción de escribanos de Juan Elías Ortiz de Logroño (Mexico: Universidad Autónoma de Querétaro, 2005); and Luján Muñoz, Escribanos.

10. Jiménez Gómez, Formulario notarial, pp. 18, 396-397, 405-411; Luján Muñoz, Escribanos, pp. 65-75. Both authors include a list of books owned by notaries.

11. Lockhart, Spanish Peru, pp. 73-74; Herzog, Mediación, p. 47. I am following Burns, Into the Archive, pp. 206-207, in the choice of the English translation of the terms 'oficial' and 'oficial mayor.'

12. The selling of public offices had been a common practice in Spain as a way of augmenting the royal treasury, and the office of 'royal and public notary' was the first to be sold in the Spanish-American colonies, in 1559. The system structure implied that the king had to approve appointments to public office, but by 1581 these posts became not only vendibles (saleable) but also renunciables (the owner could transfer it to someone else). This meant that the owner of a post could make clear his preference for a suitable successor, although a public auction sometimes contradicted his choice, as in Jorge Geronimo Perez's case introduced at the beginning of this article. Guillermo Céspedes del Castillo, "La organización institucional," in Historia de América Latina, Alfredo Castillero Calvo and Allan Kuethe, eds. (Paris: UNESCO, Editorial Trotta, 2000), vol. III-1, pp. 44-45; Luján Muñoz, Escribanos, p. 29; Herzog, Mediación, chapt. 9; and Francisco Tomás y Valiente, La venta de oficios en Indias (1492-1606), (Madrid: Instituto Nacional de Administración Pública, [1972] 1982), chapt. 1.

13. Don Felipe II, año de 1566, Novísima recopilación de las Leyes de España Dividida, 6 vols. (Madrid: 1805), Book 7, Title 15, Law II.

14. Luján Muñoz, Escribanos, pp. 25-29. 
became available and have the ownership confirmed by the monarch within five years. ${ }^{15}$ The buying of the notarial office meant paying for it and for the media annata, which was half the annual benefit accruing from it. Later, the owner could give up ownership and hand the office over to another notary. ${ }^{16}$

As in other societies and times, notaries had both notarial and judicial functions. They dealt with public and private matters and verified all public deeds. ${ }^{17}$ Depending on the kind of notarial office they owned and worked in, they usually knew everything that was going on in the cabildo, the government, or the audiencia. They were the recorders of daily matters at a time when most people were illiterate but had nonetheless to meet the demands of the colonial administration and the Church for written documents to prove ownership, marriage, calidad, origin, juridical status, and the legality of their presence in Spanish America. At a private level, they knew about such complex and often delicate matters as wills, debts, business agreements, and the selling of slaves, to give just a few examples of documents that notaries drafted, issued, and acted upon as witnesses. They frequently had considerable input into the document they were issuing, as they knew the formulas and required manner of presenting facts, though there is evidence that clients also influenced the document. ${ }^{18}$ Recent research in Cuba by Michael Zeuske and Orlando García Martínez has shown that notaries influenced the way in which former slaves were identified in the records after the abolition of slavery. ${ }^{19}$ Overall, notaries were respected, pivotal members of the local society who dealt on a daily basis with authorities and those in their jurisdictions, and their signatures were accepted as proof of truth.

In both Spain and Spanish America, notaries had to meet special criteria. The Tercera Partida of King Alfonso the Wise determined that, among other qualities, notaries had to be capable, reliable, discreet, trustworthy, and Christians of good reputation, so as to insure the respect and trust of clients and the com-

15. For irregularities in the designation of notaries during the early years of the conquest, see Luján Muñoz, Escribanos, pp. 20-24, 29-35. In Mexico, the selling and handing over of notarial offices could be confirmed by the viceroy (Jiménez Gómez, Formulario notarial, p. 16), but for Panama such transfers always had to be confirmed by the Consejo de Indias and the King. Thus, conflicts arose when the governor decided to take the initiative as in the case of Gaspar de Aguilar discussed in this article.

16. Luján Muñoz argues that with the lapse of time, the handing over office to another person became a simple formality, but in Panama this was not the case. Competition for the posts existed. Luján Muñoz, Escribanos, pp. 35-40, especially pp. 36-37.

17. Ibid., pp. 40-45.

18. On the clients' influence on the final document, see Burns, Into the Archive, pp. 79-83. For an example of difficulties a notary might face when drafting documents, see the governor of Panama's 1768 accusation against the escribano mayor for misleadingly interpreting a law in his own interest. Tello de Ugarte, "Panamá," p. 84.

19. Michael Zeuske and Orlando García Martínez, "Estado, notarios y esclavos en Cuba," Nuevo Mundo Mundos Nuevos, Débats (April 2, 2008), http://nuevomundo.revues.org/15842 (accessed April 8, 2014). 
munity at large. ${ }^{20}$ More importantly, they had to be of legitimate birth and comply with the prerequisite limpieza de sangre. ${ }^{21}$ In Spain, limpieza de sangre meant that the person was neither a descendant of conversos (Jews or Muslims who converted to Christianity) nor a heretic; it implied that the person could trace and demonstrate his genealogical origins and was of legitimate birth. ${ }^{22}$ Local and regal prohibitions dating from as early as 1449 prohibited conversos from becoming notaries, based on limpieza de sangre. ${ }^{23}$ Nonetheless, some are attested in fifteenth- and sixteenth-century Iberia. ${ }^{24}$ However, as probanzas de sangre (documents verifying that one was of pure blood) and proof of legitimate birth came to be more insistently demanded after the establishment of the Inquisition in the Spanish dominions and the issuing of new laws during the late fifteenth and early sixteenth century, it was likely that overcoming the requirement was by then more difficult.

When the concept of limpieza de sangre traveled to Spanish America, it was expanded to include a further condition: a notary could not be a person of African or indigenous descent. Although this prohibition may have been respected initially, complaints that mestizo, mulatto, and illegitimate people were working as notaries began to reach the Consejo de Indias and the king. In response, royal decrees and orders were issued to control access to the occupation and office of notary for people of mixed descent and illegitimate birth. ${ }^{25}$ The first decree was issued by King Felipe II in 1576, and it stated specifically that mulattos and mestizos could not be accepted as notaries. ${ }^{26}$ Subsequent

20. Partida Tercera, Title XIX, Laws 1 and 2. Las Siete Partidas del Rey Don Alfonso el Sabio. Cotejadas con varios códices antiguos por la Real Academia de la Historia, Tomo II, Partidas Segunda y Tercera (Madrid: Imprenta Real, 1807), pp. 633-634.

21. Jiménez Gómez, Formulario notarial, p. 19; Luján Muñoz, Escribanos, pp. 20-29; Herzog, Mediación, p. 59; Burns, "Notaries," p. 362. On the legitimacy requirement for notarial aspirants, see also Ann Twinam, "Honor, Sexuality, and Illegitimacy in Colonial Spanish America," in Sexuality and Marriage in Latin America, Asunción Lavrin, ed. (Lincoln and London: University of Nebraska Press, 1989), p. 124 note 11.

22. See Martínez, Genealogical Fictions; María Elena Martínez, "The Black Blood of New Spain: Limpieza de Sangre, Racial Violence, and Gendered Power in Early Colonial Mexico," William and Mary Quarterly 61:3 (July 2004), pp. 479-520; Ann Twinam, Public Lives, Private Secrets: Gender, Honor, Sexuality, and Illegitimacy in Colonial Spanish America (Stanford: Stanford University Press, 1999), pp. 41-50; and Albert A. Sicroff, Los estatutos de limpieza de sangre: controversias entre los siglos XV y XVII (Madrid: Taurus Ediciones, [1979] 1985).

23. It was the city council of Toledo that banned conversos from being notaries or holding public office. The royal pragmatic of 1501 banned those who did not comply with the limpieza de sangre requirement from holding a public office or civil post. Twinam, Public Lives, pp. 45-46.

24. See for instance a case in 1436 Barcelona: David Nirenberg, "Mass Conversions and Genealogical Mentalities: Jews and Christians in Fifteenth-Century Spain," Past and Present 147 (2002), p. 24; and Henry Kamen Henry, The Spanish Inquisition. An Historical Revision (London: Weidenfeld \& Nicolson, 1997), especially chapt. 3 .

25. People of African descent were also banned from becoming lawyers or doctors, carrying arms, and wearing certain clothing and jewelry, among other prohibitions.

26. Recopilación de leyes de los reynos de las Indias (Madrid: Iulian de Paredes, 1681), vol. 2, Book V, Tit. VIII, Law XXXX, p. 167r. 
royal decrees and orders were issued in 1584 for the audiencia de Santa Fé; in 1586 for Santa Fé; in 1599 for Yucatán; in 1602, 1621, and 1626 for the viceroyalty of Peru (which included the audiencia of Panama); in 1603 for Santiago (Guatemala); and in 1623 for the audiencia of Panama. ${ }^{27}$ While the next royal decree did not come until a 1750 decree for Peru again banned mestizos and mulattos from accessing these posts, other personal prohibitions and denials of access were issued in the meantime, for instance in 1692 and in the $1730 \mathrm{~s}^{28}$

Based on these laws and existing research, some historians have maintained that notaries were mostly whites, either Spaniards or descendants of Spaniards, and it is common to find assertions such as Patrick Carroll's that "whites exclusively served as priests and notaries." 29 In her recent monograph on notaries in Quito, Kathryn Burns makes no mention of notaries of color. ${ }^{30}$ Writing about seventeenth-century Quito, Herzog argues that notaries were mostly from the middle and higher strata of society, and points out that no one was accused of failing to meet the requirements of limpieza de sangre and legitimacy. ${ }^{31}$

The possibility that people of African descent could have acted as notaries during the eighteenth century has been considered by some historians, who explain the apparent disregard by the crown and the Consejo of a candidate's race as a response to difficulties in selling the offices to Spaniards, who were no longer interested. Herzog, confronted with rumors that a notary from Quito had Indian ancestors, suggested that the Consejo de Indias might have been less demanding at a time when the state was experiencing difficulties in selling these offices, arguing that it would have been more concerned with the sales

27. Panama was under the jurisdiction of the viceroyalty of Perú until 1739 , and then under the viceroyalty of New Granada. For the decrees, see Richard Konetzke, ed., Colección de documentos para la historia de la formación social de Hispanoamérica, 1493-1819, 5 vols. (Madrid: CSIC, 1953-1962). See in particular vol. 1, p. 498 (1576), p. 567 (1586), and pp. 555-556 (1584); Vols. 2-1 and 2-2, p. 61 (1599), p. 85 (1602), p. 100 (1603), pp. 259-260 (1621), and p. 280 (1623); and Vol. 3-1, p. 247 (in the text, 1626). For 1576 Venezuela and 1603 Guatemala, see Luján Muñoz, Escribanos, p. 26 notes 33 and 34. Castillero Calvo cited the years of $1584,1599,1602,1603,1621$ and 1623, arguing that 1584 was possibly the first date in which laws were issued restricting mulattos, libertos (freedmen), and mestizos. Castillero Calvo, "Color," p. 303. However, I have identified 1576 as the first date for the restrictive legislation and also located the 1586 decree.

28. The 1750 royal decree is found in Konetzke, Colección, vol. 3-1, p. 247. A royal decree denied a dispensation of color to Jerónimo Quesada in his attempt to become a public notary in 1692, ibid., p. 19. For the 1730s, see the discussion of the two notaries from Panama in the following paragraphs. It is possible that other royal decrees were issued, but I have not located them.

29. Patrick J. Carroll, Blacks in Colonial Veracruz: Race, Ethnicity, and Regional Development (Austin: University of Texas Press, 1991), p. 113; Robinson A. Herrera, Natives, Europeans, and Africans in SixteenthCentury Santiago de Guatemala (Austin: University of Texas Press, 2003), pp. 101-105.

30. People of indigenous descent were indeed notaries in their own villages and communities, and frequently wrote not only in Spanish but also in their native languages, for instance Nahuatl or Yucatec Maya. There is a large body of literature discussing those notaries, but they are not within the focus of this article. See for instance: Burns, Into the Archive, pp. 6-11 and bibliography; ibid., "Notaries," pp. 363-365.

31. Herzog, Mediación, pp. 60-62. 
than the requirements. ${ }^{32}$ The primary source Herzog used to support this statement deals with difficulties encountered by the audiencia of Guadalajara in filling the position of receptor in the late 1720s. The oidor of the audiencia stated that people did not apply, even when encouraged to do so, because the post was not well paid and because it was costly for aspirants to gather documentation to prove their origins-even though the individuals he had encouraged to apply were (publicly) recognized as Spaniards ("bien tenidos por españoles"). ${ }^{33}$ The Consejo's response was to recommend that the posts be auctioned to the highest bidder, without requesting genealogical evidence. Although the recommendation seems to reflect a concession in the approach to requirements, it is noteworthy that the candidates in question were already regarded as españoles. The recommendation was probably an attempt to facilitate the process of filling the vacancies, rather than an open door. While Herzog's interpretation may be valid, its contrast with the Panamanian cases shows that there was more to the attitude of the authorities than simply economic need.

In analyzing the case of Panama, Alfredo Castillero Calvo and Aida M. Pérez Calderón make the argument that the notarial office had stopped appealing to Spaniards in mid-eighteenth century Panama, and take this to explain the presence of so many notaries of African descent there. Both historians also attest notaries of color during the seventeenth century, and Castillero Calvo suggests that the mid-seventeenth century might have been a turning point, as some persons of African descent were accepted then into Panama's lower bureaucracy as a result of the economic crisis. ${ }^{34}$ I discuss this issue below. Castillero Calvo and Pérez Calderón also make specific reference to the argument presented by Bartolome de Salazar, a cuarterón notary who said that if he was not confirmed in the post it would be occupied by another person of mixed ancestry or would remain vacant. ${ }^{35}$ Twinam follows Castillero Calvo's work, contributing to it by stating that the impact of the Seven Years War in the Isthmus might help to explain the context in which notaries began to pay the dispensa in the 1760s, two points that this article questions. ${ }^{36} \mathrm{I}$ maintain that this argument might have been an exaggeration used by Salazar to support his case, since for the years in which I have located the names of nearly all holders of

32. Ibid., pp. 60-61 and note 108. The document is dated 1730 (see note 33).

33. Cámara de Indias, May 4, 1730. Archivo Histórico Nacional (Madrid), Códices, 758, no. 99, fols. 286-288. For the Camara's resolution, see fols. 287r-288r.

34. Castillero Calvo, Negros, p. 30; Pérez Calderón, "Política," p. 272.

35. Ibid. On Bartolome de Salazar, a cuarterón notary who obtained his fiat in 1758 and provided this argument to defend his case, see the Consejo, July 8,1758, and the decree of the King, August 20, 1758, both in AGI, Panamá, 120; and several documents of 1754 and 1758 in AGI, Panamá, 155.

36. Twinam, forthcoming. 
the notarial office (seven out of eight), between half and two thirds of the positions were occupied by Spaniards. In addition, those who failed to put forward the highest bid at auctions and consequently did not obtain the notarial offices frequently appealed the final auction, which demonstrates that they were indeed interested in the posts. ${ }^{37}$ Economically speaking, the most important notarial office in Panama City, that of War and Government, carried substantial earnings until at least the 1770 s, so it is unlikely that white notaries would not have wanted to own it. ${ }^{38}$

Thus, rather than limiting the discussion to an economic crisis, or to the occupation's lack of appeal, or both, I suggest through my research that the Consejo de Indias and the monarchs conducted an unofficial practice-albeit within an official policy and with occasional exceptions - of integrating successful, educated, able, frequently legitimate, fair-skinned people of African descent into Panama's lower bureaucracy. This practice, probably in place from the late sixteenth century and certainly by the early seventeenth, shows that despite official legislation, the crown and the Consejo retained the final word on the decision to accept or reject an aspirant to office, maintained a flexible approach, and could choose to disregard the candidate's calidad and illegitimate birth at their convenience. ${ }^{39}$ In the documentation accompanying the petitions, there is no discernible change in argument over time, except for a concern expressed in the late seventeenth century by some fiscales who wanted to know if the granting of dispensations had to be accompanied by a payment. The first examples of payment date from the late seventeenth century, but payments were not routinely made even in the mid-eighteenth century. Thus, it seems that the practice of payment was not affected by the progressively intrusive Bourbon reforms. Indeed, it did not become an official act until 1795 with the gracias al sacar.

I suggest that the setting aside of requirements regarding legitimacy and origin is surprising, but only to a certain degree. I have already mentioned that there were conversos working in the Spanish bureaucracy. Twinam has shown that

37. Competition did exist. People of color did not occupy notarial offices "almost by default" as was suggested by Castillero Calvo, La sociedad panameña. Historia de su formación e integración (Panamá: Comisión de Estudios Interdisciplinarios para el Desarrollo de la Nacionalidad, 1970), p. 102, and incorporated by Frederick P. Bowser, "Colonial Spanish America," in Neither Slave nor Free: The Freedman of African Descent in The Slave Societies of the New World, David W. Cohen and Jack P. Greene, eds. (Baltimore and London: John Hopkins University Press, [1972] 1974), p. 49.

38. Francisco Nicolas de Aizpuru to Governor, February 13, 1777, AGI, Panamá, 284; and Tello de Ugarte, Panamá, 81-82.

39. Only a few times were candidates' petitions for a fiat or notarial office denied in Panama, and those coincided in time and are discussed in the following paragraphs. On the gracias al sacar, see among others James F. King, "The Case of Jose Ponciano de Ayarza: A Document on Gracias al Sacar," Hispanic American Historical Review 31:4 (November 1951), pp. 640-647; and Twinam, Public Lives. 
illegitimacy could be obliterated for Spaniards or whites well before the late eighteenth-century gracias al sacar decrees, if the king and the Cámara consented. ${ }^{40}$ The cases she studied clearly demonstrate that people did bypass the law, and in doing so were sanctioned by the highest authorities. In looking at possible economic reasons that members of the Consejo de Indias might have come to agree to legitimization petitions in the eighteenth century, Twinam suggests that there was no direct connection between these agreements and the fees paid to obtain the Cámara's decisions until the issuance of the gracias al sacar price list of 1795 . The Cámara did not set prices. Although Twinam did identify a trend toward financial considerations through the course of the eighteenth century, and the 1795 decree was certainly revenue-motivated, Cámara members did not themselves participate in the drafting of the decree, and furthermore did not necessarily agree on its terms and implementation. ${ }^{41}$ While Twinam's forthcoming study argues that the Panamanian cases probably set the exact amount to be paid for some of the future gracias al sacar fees (for instance, the cases for quinterónes), there is no evidence in the cases analyzed that money was the only motivation for accepting people of African descent as notaries. The argument seems all the more valid because payment for the dispensation was inconsistently introduced during decades of practice. The impact of individual cases on the royal treasury was limited, especially given that there was no official decree encouraging persons of color to apply for this dispensation until 1795. I thus suggest that economic motives were not the only reason for the acceptance of African-descended candidates into the occupation of notary, although the state would always welcome money.

In regard to calidad, there is no evidence that the agreement of the monarchs and the Consejo to grant a dispensation of color implied an official change to the notarial aspirant's reputation or status. Paying for the dispensation of color granted a man the official title of notary, which recognized his abilities and provided him with public recognition and respect, but it did not officially modify his public status as a man of color or the manner in which he was addressed in public. Although it is necessary to acknowledge that the authorities were providing notarial appointees with an advance in socioeconomic status by giving them a place within the lower bureaucracy, and were conveying to them a degree of respectability and public recognition that a person of African descent would otherwise have had difficulties achieving, the occupa-

40. Despite some temporary provisions for local authorities to legitimize people, the Consejo de Indias had the right to the last word on legitimizations. Twinam, Public Lives, p. 52. For legitimizations of Spaniards between the late fifteenth and mid sixteenth centuries, see Public Lives, pp. 50-51. For conversos whose origins were obliterated by the King, see Public Lives, pp. 42-43. Twinam discusses the 1773 decree of gracias al sacar for Spain in her forthcoming book.

41. Twinam, Public Lives, pp. 246-261, 290-297 (for the 1795 decree). 
tion remained a low position in the bureaucracy, one from which little harm could be done to the imperial structure. The dispensation of color did not obliterate a man's African ancestry, and his sons also had to apply for it if they wished to work in or inherit his business.

The question remains: why did the Crown maintain such dual unofficial/official practice toward notaries of color? Research on calidad and identity in Colonial Latin America has demonstrated that in day-to-day life it was not only skin color and genealogy that determined a person's place in society, but occupation, social network, wealth, culture, appearance, and behavior, among other aspects. ${ }^{42}$ One possibility could be that the Consejo de Indias and monarchs acknowledged this fact and extended the same degree of flexibility they had shown with illegitimacy to grant dispensations that would allow appropriately trained and otherwise suitable candidates of African descent to become notaries. These nominal dispensations would not have created a revolution or provoked a storm of petitions, so adapting the law to suit an existing local reality may not have seemed a threatening move for the empire, especially since these petitions remained few and unpublicized. It seems as though authorities were integrating local perceptions and approaches on calidad into some of their decisions, even though nothing they recorded specifically states this intent. Thus, rather than placing sole emphasis on economic difficulty or crisis, it would be enlightening to add to the equation the colonial social reality and the flexibility of Spanish imperial law and administration.

\section{PANAMA AND ITS NotARIES: EXCEPTION OR Not?}

The 42 notaries of color attested in Panama are an exceptional group, but the key issue is whether Panama as an entity was an exception, or if people of African descent legally worked as notaries elsewhere in the Spanish American colonies. The legislation banning people of mixed ancestry from becoming notaries, first instituted as early as the late sixteenth century, clearly responded to complaints put forward by competitors and zealots. The very promulgation of such legislation, however, indicates that people of African descent were already becoming notaries, although the evidence remains scarce.

Published research has been fruitful in identifying notaries of color elsewhere in Spanish America. For seventeenth-century Lima, Frederick Bowser located a mulatto who obtained the title of notary in the late 1630s, thanks to his "talent and influential friends." He was born in Badajoz (Spain) and had

42. See Seed, Vinson, and Mangan among others listed in note 7. 
trained and worked in the office of a notary before moving to Lima, where he paid 100 ducats for the title of notary. The audiencia refused to grant it to him, but the king overruled the audiencia and conceded it. ${ }^{43}$ Bowser also identified a man who bought the office of procurador of the audiencia and was then accused of being a mulatto by members of the same institution. Defending him, a professor of law at the University of San Marcos in Lima argued that "he was not really a mulatto, but a quadroon, that he was a person of unquestioned ability, and that he had paid twice as much for the office $(6,000$ pesos $)$ as any previous holder." 44 Luján Muñoz located three notaries whose origins were investigated. One was of mixed Indian and mulatto ancestry and another the mulatto grandson of a black woman in Nueva Veracruz, Mexico. ${ }^{45}$ The third, don Sebastián Coello Nuñez, was a royal and archbishop's notary; he was accused of being pardo in Santiago de Guatemala in 1679. ${ }^{46}$

It is possible that the three cases analyzed by Luján Muñoz arose from false accusations and rumors intended to discredit the holders of notarial fiats. Accusations of African ancestry, it is true, would provoke questions about a fiat-holder's public reputation and standing in society. However, the two cases reported by Bowser demonstrate that the notaries were respected and had the support of some well-known and distinguished locals. Other notaries and Spanish officials also mention notaries of African descent in Spanish America. For instance, Bartholome de Salazar stated that in Tolís (Cartagena), a cuarterón had been granted the fiat of public notary in 1731, and other Panamanian notaries mentioned cases in mid-seventeenth century Lima and Callao, as discussed below. ${ }^{47}$ These cases represent a small number in comparison to the Panamanian figure, but they demonstrate that people of African descent with the right training and network support were able to become notaries elsewhere in Spanish America. There is no reason to doubt that further research might reveal new cases.

All but one of the 42 notaries identified in Panama and listed in Table 1 obtained the fiat, and most also owned a notarial office. ${ }^{48}$ It is very likely that others worked as assistants in the offices of notaries but, as they never applied

43. Frederick P. Bowser, The African Slave in Colonial Peru, 1524-1650 (Stanford: Stanford University Press, 1974), p. 314; Bowser, "Colonial Spanish America," p. 48.

44. Bowser, "Colonial Spanish America," p. 48.

45. Luján Muñoz, Escribanos, p. 26 note 36 (dates not specified).

46. Ibid., p. 27. The fact that he was addressed as 'don' might suggest that he was not of African descent, but evidence from Panama might raise doubts about this assumption (see the discussion of the Aizpuru family in this article).

47. "Bartholomé de Salazar, vezino de la ciudad de Portobelo ...," 1736, AGI, Panamá, 152.

48. People of indigenous descent might also have been notaries in Panama, but so far only one mestizo descendant of "Indians from Quito" has been found to have been granted the fiat in Panama, in 1705. See Pérez Calderón, "Política y sociedad," p. 280 note 86. 
for the fiat or for ownership of a notarial office, I have not been able to identify them. Details regarding the careers of these 42 were painstakingly collected from multiple sources including lawsuits, petitions, letters, decrees, reports, and descriptions located in the Archivo Histórico Nacional (Madrid) and the Archivo General de Indias (Seville), as well as from secondary sources. Notarial registers do not exist for Panama until the very late eighteenth century and the few partial lists available in Seville are incomplete and do not record dispensas or the origin of the recipient; thus it is possible that further research will bring to light more names. ${ }^{49}$ Nevertheless, the current sample is representative. For some years it identifies two or three colored notaries out of a total eight, which was the maximum number of notaries in office in any given year, as demonstrated in the documentation for Panama City in 1647 and $1774 .{ }^{50}$ From Table 1 , it can be concluded that at least one notary of African descent was in office at any given time during this period, while in some years-for example, 1692, 1725 , and 1745 - there were three or four.

\section{TABLE 1}

\section{Notaries of Color in Panama, Seventeenth to Nineteenth Centuries}

Table Key: ${ }^{*}=$ petition $\quad c$. $=$ circa $\quad \dagger=$ year of death $\quad ?=$ unclear $\quad$ italics = petition denied A table entry without a footnote indicates that the notary mentioned is discussed elsewhere in this article.

\begin{tabular}{lcll}
\hline Years as Notary & Year of Fiat & Panama City & $\begin{array}{l}\text { Other } \\
\text { Panamanian Cities }\end{array}$ \\
\hline Before 1615-1622-? & 1615 & Alonso de (la) Torre(s) ${ }^{51}$ & \\
Before 1619-1622-? & 1619 & Joseph Nuñez (de Prado) $)^{52}$ & \\
1620s-1650-? & 1650 & Manuel Botacio Grillo &
\end{tabular}

49. During my research period in Panama, the Archivo Nacional was moving its notarial records. I was thus able to access the 1790 s records only on printed versions of very low-quality digitized images that made reading them extremely difficult. Regarding documents in Seville, I refer to AGI, Panamá, 246, which includes register books with minutas for the second half of the eighteenth century; AGI, Panamá, 247, with partial lists of notaries mostly for the eighteenth century, including the only reference to a dispensa; and Expedientes de confirmación de oficios vendibles y renunciables, vol. II: audiencias de Guadalajara, Guatemala, Filipinas, Panama y Lima (Seville: Archivo General de Indias, 1993).

50. For 1647, see Súplica de la Ciudad de Panama al Rey vista en el Consejo, July 1, 1647, AGI, Panamá, 31, N.49. For 1774, see Tello de Burgos, "Panamá," pp. 82-83. The 1607 description for Panama City stated that there were 25 notaries, which might have been an exceptional circumstance: "Descripcion de Panama y su provincia sacada de la relacion que por mandado del Consejo se hizo y embio a aquella Audiencia,” 1607, Biblioteca Nacional Madrid, Manuscritos, sig. 3064, Descripción de Indias, vol. 1, fols. 53-82; and "Descripción de Panamá," fol. 64r.

51. Alonso de Torres (or Alonso de la Torre) had his fiat confirmed on September 7, 1615. See AGI, Panamá, 56, N.3, as listed in Expedientes de confirmación, vol. II, p. 258.

52. Joseph Nuñez de Prado had his fiat confirmed on February 6, 1619. AGI, Panamá, 56, N.23, as listed in Expedientes de confirmación, vol. II, p. 262.

53. AGI, Panamá, 101, N.124a, fol. 532r. On April 6, 1650. He did not pay a dispensation of color despite being mulatto from his mother's side. Sometimes he is mentioned as Grilo. 


\begin{tabular}{|c|c|c|c|}
\hline Years as Notary & Year of Fiat & Panama City & $\begin{array}{l}\text { Other } \\
\text { Panamanian Cities }\end{array}$ \\
\hline Before 1661-1770-? & 1661 & Juan Franco ${ }^{54}$ & \\
\hline c. $1642-1661-?$ & 1661 & Juan Martinez de Leguizamo 55 & \\
\hline Before 1670-? & Unknown & Juan Lopez de Motos ${ }^{56}$ & \\
\hline Before 1669-1683-? & 1679 & & $\begin{array}{l}\text { Alonso de Alarcon } \\
\text { (Portobelo) }\end{array}$ \\
\hline Before 1689-? & 1689 & Silvestre Botacio Grillo ${ }^{57}$ & \\
\hline Before 1691-1740-? & 1691 & Joseph de Avellaneda (father) ${ }^{58}$ & \\
\hline Before 1688-1692-? & 1692 & & $\begin{array}{l}\text { Miguel Perez } \\
(\text { Portobelo })^{59}\end{array}$ \\
\hline Before 1694-1730 & 1694 & Juan Joseph Franco ${ }^{60}$ & \\
\hline Before 1713-1738-? & $1713 ?$ & Juan Ignacio de Aizpuru & \\
\hline 1712?-1740-? & $1725 \& 1740$ & Jorge Geronimo Perez & \\
\hline Before 1729-? & 1729 & 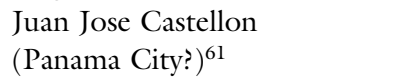 & \\
\hline 1720s-1735-? & $1735^{*}$ & Francisco Escartin & \\
\hline Before 1729-1758-? & $1736^{*}-1758$ & & $\begin{array}{l}\text { Batholome de Salazar } \\
\text { (Portobelo) }\end{array}$ \\
\hline Before 1738-? & $1738^{*}$ & & 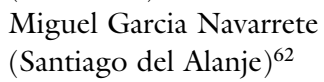 \\
\hline
\end{tabular}

54. Juan Franco, vecino of Panama City and cuarterón (specified as son of español and mulata) was granted the notarial office in 1661, only to be questioned and confirmed in his post by the governor of Panama in 1670 . He did not pay for the dispensation of color but made clear that he was a cuarterón. AGI, Panamá, 101, N.124a, fol. 533r.

55. His fiat as notary was confirmed on September 12, 1661. AGI, Panamá, 57, N.77, as listed in Expedientes de confirmación, vol. II, p. 287. Castillero Calvo, “Color,” pp. 305-306, argues that Leguizamo's witnesses highlighted his fair skin as a positive trait.

56. He had bought a notarial office but did not receive a dispensa for his defecto of cuarterón de mulato. However, he was later (1670) made to pay 75 pesos for the dispensation of color. AGI, Panamá, 101, N.124a, fol. $533 \mathrm{r}$

57. Son of Manuel Botacio Grillo, he obtained the notary office in 1689, and paid 200 escudos for the dispensation of color ("la mezcla de mulato"). AGI, Panamá, 101, N.124a, fol. 533r. See also AGI, Panamá, 60, N.7, as listed in Expedientes de Confirmación, vol. II, pp. 299-300.

58. Joseph de Avellaneda had his fiat and the position of receptor of the audiencia of Panama confirmed in 1691. AGI, Panamá, 60, N.8, as listed in Expedientes de confirmación, vol. II, p. 300. He is also mentioned in Testimonio de los Autos sobre la postura que hizo Jorge Gerónimo Pérez, AGI, Panamá, 153; King to audiencia of Panama, July 20, 1740, AGI, Panamá, 119; and "Petición de fiat de escribano y notario por Eusebio Joseph Gomez," May 24, 1747, AGI, Panamá, 154.

59. Miguel Perez to Don Gaspar de Medina, April 9, 1691, AGI, Panamá, 101, N. 124b, fol. 536r. He obtained the notary office, and also paid 100 pesos for the dispensation of color ("el color de mulato que tiene por parte de madre") in 1692. AGI, Panamá, 101, N.124a, fol. 532r. For 1688, see AGI, Panamá, 101, N. $124 \mathrm{c} 539 \mathrm{r}-542 \mathrm{v}$. He had also been ecclesiastical notary in Portobelo.

60. His fiat was confirmed on June 9, 1694. See AGI, Panamá, 60, N.15, as listed in Expedientes de Confirmación, vol. II, p. 301, r.4814. I have attested him in 1705, 1707, 1719 and 1730. "El testimonio del nombramiento que se dio por el Superior Gobierno a Jorge Gerónimo Pérez escribano de la visita del Reino," 1739, AGI, Panamá, 154.

61. "Bartholome de Salazar, vezino de la ciudad de Portobelo," 1736, AGI, Panamá, 152.

62. "Sobre el escribano publico de Cabildo de Santiago," 1738, AGI, Panamá, 153. 
TABLE 1 (continued)

\begin{tabular}{|c|c|c|c|}
\hline Years as Notary & Year of Fiat & Panama City & $\begin{array}{l}\text { Other } \\
\text { Panamanian Cities }\end{array}$ \\
\hline Before 1732-1740-? & 1740 & Joseph de Avellaneda (son $)^{63}$ & \\
\hline Before $1733-1779$ & 1742 & Francisco Nicolas de Aizpuru & \\
\hline 1732-1754-? & 1747 & Eusebio Joseph Gomez & \\
\hline Before 1749-? & 1749 & Juan de Dios Orencio Perez & \\
\hline Before 1753-1779-? & 1753 & $\begin{array}{l}\text { Manuel Joseph Lopez } \\
\text { (1755 onward) }\end{array}$ & $\begin{array}{l}\text { Manuel Joseph Lopez } \\
\text { (Portobelo, 1753-1755 }\end{array}$ \\
\hline$?-1750 s-?$ & Unknown & Bernardo Joseph Gomez & \\
\hline Before 1754-? & c. 1754 & Laureano Garcia Alzamora & \\
\hline Before 1755-1778-? & 1755 & & $\begin{array}{l}\text { Gaspar de Aguilar } \\
\text { (Santiago de Veragua) }\end{array}$ \\
\hline Before 1754-? & Unknown & $\begin{array}{l}\text { Pedro Joseph Masso } \\
(\text { or Mazo })^{64}\end{array}$ & \\
\hline$?-1750 s-?$ & Unknown & & $\begin{array}{l}\text { Pedro Cayetano Escobar } \\
\text { (Santiago de Veragua) }\end{array}$ \\
\hline Before 1750-1774-? & 1761 & Carlos Santos de la Peña & \\
\hline Before 1667-? & $1767^{*}$ & Juan Evaristo de Jesus Borbua & \\
\hline Before 1766-1778-? & Unknown & & $\begin{array}{l}\text { Miguel Angel Rivas } \\
\text { (Santiago del Alanje) }\end{array}$ \\
\hline Before $1777-1779 \dagger$ & 1778 & $\begin{array}{l}\text { Miguel Santiago del Cid } \\
\text { (or del Sid) }\end{array}$ & \\
\hline $1750 s-1778-1808-?$ & 1778 & Ciriaco Hipolito Correoso & \\
\hline Before 1778-? & $1778 ?$ & & Joseph Antonio \\
\hline 1782-? & & & $\begin{array}{l}\text { Bustamante } \\
\text { (Villa de los Santos) }^{65}\end{array}$ \\
\hline Before 1778-? & $1778 ?$ & Francisco de Arosemena ${ }^{66}$ & \\
\hline Before 1781-? & 1781 & & 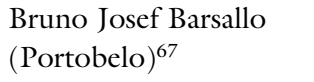 \\
\hline Before 1785-? & 1785 & & $\begin{array}{l}\text { Francisco Homboni } \\
\text { (Portobelo) }\end{array}$ \\
\hline Before 1783-1796-? & 1786 & $\begin{array}{l}\text { Luis Joseph de Paz } \\
\text { (at least from 1796) }\end{array}$ & 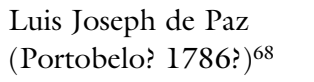 \\
\hline Before 1786-1786-? & Unknown & Josef Patricio de Aizpuru ${ }^{69}$ & \\
\hline
\end{tabular}

63. Bartholome de Salazar, vezino de la ciudad de Portobelo, 1736, AGI, Panamá, 152.

64. Twinam, forthcoming, argues that he was a notary of African descent. I have been able to attest him as receptor and notary throughout the 1750s. See for instance AGI, Panamá, 254, document listing receptores in Panama City (1734-1754).

65. He was a notary of the Cabildo de Los Santos. Bibiano Torres Ramírez, Juana Gil-Bermejo García and Enriqueta Vila Vilar, eds., Cartas de Cabildos Hispanoamericanos. Audiencia de Panamá (Seville: EEHACSIC, 1978), p. 384, doc. 691 (year 1778).

66. "Testimonio del expediente sobre dispensa de calidad," May 31, 1778, AGI, Panamá, 284.

67. AGI, Panamá, 246, "Inventario de minutas de despachos desde 1760-1781," fol. 295r. It is stated that it was with a dispensa de color for a pardo, and this is the only mention of dispensas in the register book. 68. Twinam, forthcoming, cites the case of Luis Joseph de Paz in AGI, Panamá, 286, N.4. On his move to Panama City, see AGI, Panamá, 254, document listing notaries in Panama City, February 14, 1796.

69. AGI, Panamá, 254, document listing notaries in Panama City, March 4, 1786. 
TABLE 1 (continued)

\begin{tabular}{lcll}
\hline Years as Notary & Year of Fiat & Panama City & $\begin{array}{l}\text { Other } \\
\text { Panamanian Cities }\end{array}$ \\
\hline $\begin{array}{l}\text { Before 1786-? } \\
\text { Before 1791-? }\end{array}$ & Unknown & Juan Ignacio de Aizpuru & \\
& 1791 & & $\begin{array}{l}\text { Pablo Joseph de } \\
\text { Peñaranda (Unknown) }\end{array}$ \\
Before 1792-? & 1793 & Joseph Ramos $^{72}$ & \\
Before 1803-? & Unknown & Mathias Joseph Barbua $^{70}$ & \\
\hline
\end{tabular}

Source: See notes 51 through 72 .

Why there were so many notaries of color in Panama is not clear, and a few interpretations have been put forward. ${ }^{73}$ Castillero Calvo has tried to explain the numerical increase he identified in the mid-seventeenth century by looking at imperial legislation and local complaints about problems in filling the positions. In 1620, a person living in the Isthmus took his concerns directly to the king, arguing that whites had lost their interest in notary positions since mulattos had started to hold these offices. In 1622, another complaint reached the king, this one denouncing local officers who in examining potential notaries demonstrated more interest in their capabilities than in their calidad. In this context, Castillero Calvo states that the mulattos Alonso de la Torre and Joseph Nuñez had "managed to circumvent the prohibitions to work as notaries" by $1622 .{ }^{74}$ Using this evidence, Castillero Calvo argues that notaries of color had been tolerated in the notarial offices of Panama City up to 1622, and that it was the royal decree of 1623 that banned people of African ancestry from serving as notaries in Panama. ${ }^{75} \mathrm{He}$ posits that the prohibition remained in place until the late 1640s, and suggested that what he called "the gradual replacement of the white minority by a "mulatto bureaucracy" was closely connected with the economic decay of the 1640s, which reduced the appeal of

70. Ibid.

71. Alberola, "Panamá au XVIII'̀me siècle," p. 279.

72. Ibid; AGI, Panamá, 254, document listing notaries in Panama City, November 27, 1795, and January 20,1812 .

73. The incomplete demographic data available suggests that Panama had a relatively high proportion of free people of African descent by the late eighteenth century (about 55 percent in Panama in 1789, and 65 percent in Panama City in 1790). In contrast, the proportion was very small in the early seventeenth century, about 11 percent for Panama City in 1607. It does not seem that such a small proportion had a significant effect on the early emergence of notaries of African descent, although by the eighteenth century, demography may have ensured a pool of candidates, at least in Panama City. In any case, Panama City does not seem to have had more than 8,000 inhabitants at any one time in the early modern period. For a discussion, see Silvia Espelt-Bombín, "A Free Coloured Elite? Trade, Identity and Social Mobility in Panama City, 1700-1770" (Ph.D. diss., Newcastle University, 2011), pp. 39-58.

74. Castillero Calvo, “Color," p. 304.

75. Ibid., pp. 304-306. 
the post of notary for whites and allowed the introduction of people of African descent into notary posts.

Castillero Calvo supports this interpretation with reference to two other documents. ${ }^{76}$ The first is a complaint from the members of Panama's cabildo to the king in 1647, stating that there were not enough notaries in the Isthmus and that many posts were empty. ${ }^{77}$ The second was the granting of a fiat to the mulatto Manuel Botacio Grillo, the natural son of the Genoese Benito Botacio and Mariana Sanchez, a mulata or morena criolla. Born in Caracas in the early 1610s, Botacio Grillo had worked as a notary there and in Santo Domingo and Cartagena before settling in Panama City, where he applied for the fiat in 1646 and obtained it in $1650 .^{78}$ Although his mother was a mulata, he was said to be a legitimate son and grandson; it is possible his parents married after his birth. ${ }^{79}$ In his application, he had the support of his relatives and several wellknown persons in Panama City, who argued that he had good qualities as a notary, as a person, and as a Catholic, and highlighted that he was "of moderate color despite being a mulatto." ${ }^{80}$ With this evidence, Castillero Calvo proposed that Manuel Botacio Grillo may have paved the way for future notaries of color, and that the 1640s were the probable turning point for the gradual substitution of whites by notaries of African descent. ${ }^{81}$

However, additional research and an alternative analysis of both the royal decree of 1623 and the cabildo's petition of 1647 allow for another plausible interpretation. First, although it is unclear at this point whether Alonso de la Torre and Joseph Nuñez had dispensations of color, their fiats had been confirmed by the king, so they did not technically break the regulations. ${ }^{82}$ Second, the 1623 royal decree was issued specifically for the audiencia of Panama, to settle the disputes that misunderstandings of the royal decree of 1621 for the viceroyalty of Peru (to which Panama then belonged) had caused in the Isthmus. As Castillero Calvo has pointed out, the 1623 decree prohibited mulattos from holding notary posts from the date of issue of the decree, but a clause in that same decree stated that mulattos who already held office and had had their

76. Ibid, pp. 304-305; Castillero Calvo, Negros y mulatos, p. 30.

77. Castillero Calvo, "Color," pp. 304-305.

78. His fiat was confirmed on March 18, 1650. See AGI, Panamá, 57, N.56, fol. 1, regarding the parents. He is also listed in Expedientes de confirmación, vol. II, p. 284.

79. "Por ser de padres y abuelos hombre noble y bien nacido," Madrid, June 1646, AGI, Panamá, 49, N.90; AGI, Panamá, 57, N.56a, fol. 1.

80. "De moderado color no obstante que es mulato." Castillero Calvo, "Color," p. 305

81. Ibid., pp. 305-306.

82. Alonso de la Torre had his first fiat confirmed on September 7, 1615. See AGI, Panamá, 56, N.3, as listed in Expedientes de confirmación, vol. II, p. 258. Joseph Nuñez received his fiat as royal scribe and notary on February 6, 1619. See AGI, Panamá, 56, N.23, Expedientes de confirmación, vol. II, p. 262. 
titles confirmed by the Consejo de Indias were to keep their posts. ${ }^{83}$ That is, notaries of African descent already in office with all the documentation in order were allowed to continue working, despite their origins and the new decree. The decree was probably aimed at appeasing complaints rather than preventing African descendants from being notaries. This interpretation could be further reinforced by the fact that one boy of African descent was apprenticed as a notary around 1642 in Panama City. ${ }^{84}$ This demonstrates that the local perception was that the occupation was not barred to people of color-it could still be considered by parents as a career choice for their sons.

Third, although the cabildo had complained to the king in 1647 that there were too few royal notaries in the Isthmus, its main grievance was that the eight existing notaries were not available when the cabildo needed them. Thus, I propose that the letter of 1647 does not reflect a lack of notaries, but dissatisfaction with their unavailability. When they were needed, the complaint stated, they were either being used by other local institutions and authorities, or the notaries themselves prioritized their interests and other occupations over the cabildo's needs. The cabildo's petition requested that two notaries have exclusive dedication to the cabildo at any given time and that the others be made available in case of need. ${ }^{85}$ This re-analysis makes clear that the Cámara and the king were not unwilling to have people of color working as notaries, and does not support a turning point in the attitude of potential candidates toward the occupation of notary in the 1640s. Rather, it seems that persons of African descent had worked in notarial offices from at least the 1610s, if not earlier, and that they were accepted by the king, the Consejo and some local authorities. These facts support the notion of an imperial practice that ran parallel to the official position and legislation but not in concordance with them.

Manuel Botacio Grillo's fiat application and its granting by the Consejo de Indias sheds further light on the institution's approach and provides an insight into the thinking of those who made decisions and wrote reports for the Consejo de Indias on the issue. ${ }^{86}$ The Consejo asked the informants about the appropriateness of Manuel Botacio Grillo's petition and whether they knew any notaries of color in Spanish America. One, writing in Madrid in 1646,

83. "RC [Real Cédula] Que los mulatos no puedan ser escribanos," October 15, 1623, in Konetzke, Colección, vol. $2-1$, p. 280 doc. 180.

84. Juan Martinez de Leguizamo was born in 1629, put into apprenticeship when he was 13 (c. 1642), and obtained the fiat in 1660 . His case is discussed by Castillero Calvo, who does not however mention the implications regarding career prospects for children of African descent. See Castillero Calvo, "Color," pp. 305-306.

85. "Súplica de la Ciudad de Panama al Rey vista en el Consejo," July 1, 1647, AGI, Panamá, 31, N.49.

86. See the two reports in AGI, Panamá, 49, N.90a and N.90c. 
reported that he knew Joseph Nuñez de Prado, a royal notary and procurador in the audiencia of Lima; Bernardino de Espinosa, a mulatto notary in Callao; and four other notaries who had been examined and had presented dispensas de calidad in the Lima-Callao area while he was oidor there. ${ }^{87}$ His main concern was that notaries of African descent had been sent to locations inhabited by indigenous people, where they were a bad influence due to their "cruel nature" and their "abuse of power." They were feared by the indigenous people, he said, and suggested they not be sent there. ${ }^{88}$ Another report stated that there were some mulatto notaries in the Indies, some of whom had not declared their origins, but that there were others who had done so and paid for a dispensation. However, he argued that the accepted standard was that mulattos could not be notaries, because holding the office "required them to be legitimate, while they are normally illegitimate [espurios] or born out of wedlock [adulterinos]." 89 These reports demonstrate that the Consejo was aware that people of African descent were working as notaries, even though it was not officially allowed and not everyone held them in high regard. After considering these reports, the Consejo and the king conceded the fiat and dispensation of color-for which they received no payment-to Manuel Botacio Grillo in 1650. Perhaps this was because he was legitimate, had the required experience, and would not be working among indigenous people. ${ }^{90}$

\section{The Requisites: Limpieza de SANgRe ANd Legitimacy}

I have argued thus far that the crown and the Cámara were ready to overlook the African ancestry of a notarial candidate, that is, they were not concerned exclusively with the calidad of the applicant. The three salient requirements to become a notary were limpieza de sangre, the expertise to perform the job, and legitimate birth. While expertise was always a sine qua non, analysis shows that not only African ancestry but also illegitimate birth could be overlooked. To consider the consistency of attention to these requirements over the years, and which requirement carried greater weight in the application process, I analyze in this section the process of becoming a notary for some individuals and families of notaries. Along the way, this prosopographical analysis will help assess the degree to which notaries of African ancestry were integrated into colonial Panamanian society.

87. Bernardino de Espinosa was confirmed as notary public of the council of El Callao on January 21, 1626. AGI, Lima 185, N.24, as cited in Expedientes de Confirmación, vol. II, p. 439.

88. "Usar mal de la mano que les da el oficio y su natural es cruel y muy temido de los indios." Indigenous people were considered unable of acting and reasoning ("gente incapaz y desventurada"). Madrid, June 1646, Fernando de Saavedra, AGI, Panamá, 49, N.90a.

89. June 1646, AGI, Panamá, 49, N.90c.

90. 1650, AGI, Panamá, 101, N.124a (fol. 532r). 
Some notaries experienced trouble with metropolitan authorities because of their African ancestry. Francisco Escartin, natural son of don Francisco Escartin and the parda Maria Feliz de Loaysa, petitioned for the fiat in 1735 but had it denied by the Consejo de Indias, even though other notaries of African descent had been granted it during the same decade (Table 1). ${ }^{91}$ The fiscal argued that Escartin could not obtain the fiat because his mother was a parda, and people of color were not allowed to be notaries by law. However, the fiscal also stated that the fact that Escartin was a natural son was not a problem, as there were precedents. The reasoning behind the rejection of Escartin resolution seems contradictory, as there were precedents for waiving both requirements in the records of the Consejo. Just a year later, the cuarterón Bartholome de Salazar also had his fiat application denied. He was the natural son of a mulata and a militia sergeant named don Juan Phelipe de Salazar, and had worked as oficial mayor in a notary office since the 1720s. ${ }^{92}$ The two negative responses issued by the Consejo in the mid 1730s very likely correspond to the decisions of a single individual working there at the time who may have been opposed to granting fiats to people of African descent. The exceptional nature of this circumstance is made evident by the fact that Salazar petitioned again for the fiat in 1754 and obtained it at the end of a four-year process, paying for the dispensation of color. ${ }^{93}$ This case also demonstrates that although the procedures of paying for the fiat and the media annata and obtaining the dispensation (though not always by paying for it) might seem to have been standardized, this was not always the case.

In some instances, notaries whose African ancestry caused them problems with local authorities were defended by the Consejo and the king. Such was the case with Manuel Joseph Lopez, a quinterón who bought a notarial office in Portobelo in 1753 and had it confirmed by the king in 1754, even though he had not paid for a dispensation of color. ${ }^{94}$ In 1755 , the audiencia of Santa Fé (the audiencia of Panama was terminated in 1751) undertook proceedings to suspend him from his post, arguing that he had not declared that he was a quinterón when he requested the fiat. The recommendation from the Cámara's fiscal, accepted by the king, is enlightening. Although Manuel had not specifically stated his calidad in his application, he did mention that his mother was

91. Francisco Escartin to King and resolution from the Consejo, both September 1, 1735, AGI, Panamá, 152. Pérez Calderón, "Política," p. 273, refers to him as Francisco Escartin de Lort.

92. The Consejo denied his request for fiat on March 11 , and again on November 9, 1736. He had submitted the petition in the late 1720s. "Bartholome de Salazar, vezino de la ciudad de Portobelo ...," 1736, AGI, Panamá, 152.

93. Consejo, 1754-1758, AGI, Panamá, 155; Consejo, July 8, 1758, and the King, August 20, 1758, AGI, Panamá, 120.

94. The King, October 14, 1753, AGI, Panamá, 120; Pedro Díaz de Mendoza, 1753(?), AGI, Panamá, 154; Suplica de Manuel Joseph Lopez, Consejo, September 12, 1753; En la Ciudad de Panama, September 28, 1754, AGI, Panamá, 155. See also the King, October 19, 1754, and April 16, 1755, AGI, Panamá, 120. 
a cuarterona in the supporting documents. Hence, the Consejo and the king were aware of Manuel's ancestry and inability to meet all the requirements of calidad when they granted him the title and ordered the audiencia and other authorities to accept his fiat. ${ }^{95}$ Manuel continued to work for the Caja Real until at least 1779 , when I last attested him. ${ }^{96}$

Manuel Joseph Lopez's case also shows that there were sometimes irregularities in the way petitions were presented. For example, he did not ask or pay for a dispensation of color, even though it was he himself who had made it known that he was of African descent. On the other hand, sometimes people of African ancestry whose documents did not show evidence of it saw fit to declare it immediately. This is what the Laureano Garcia Alzamora did in the mid 1750s: he disclosed that he was a cuarterón when applying for the fiat, even though it was not recorded on his baptismal certificate. Most likely, his parents were fairskinned, or their social position had prompted the priest not to note their African ancestry. Garcia Alzamora pointed to this omission in his birth record as proof that he was fair-skinned enough to be socially acceptable. ${ }^{97}$ This argument was also presented by the witnesses who declared in favor of Manuel Botacio Grillo in the 1640s and Juan Martinez de Leguizamo in the 1660s, and in the two seventeenth-century Lima cases analyzed by Bowser. ${ }^{98}$

The use of baptismal records to demonstrate the genealogy of an applicant and consequently his calidad and the legitimacy of his birth is evident in the case of Ciriaco Hipolito Correoso, a natural son whose father officially recognized his paternity. Ciriaco was a cuarterón born in 1743, and he was recorded in the Panama City cathedral's baptismal book for people of color as the son of the free parda Rosa Clavijo. Although no father was recorded, his godparents were members of the elite. ${ }^{99}$ In 1768, a priest searched out Ciriaco's baptismal certificate to add a marginal note specifying that his father was don Domingo Correoso. Significantly, Domingo recognized his son in the year Ciriaco turned 25, which was the minimum age required to request the fiat. ${ }^{100}$ Ciriaco had been an apprentice in the office of the notary Francisco Nicolas de Aizpuru from an early age, and Aizpuru would later pass on to him, in 1778, the notar-

95. El fiscal en vista del memorial de Manuel Joseph Lopez, April 1755, AGI, Panamá, 155. See also Consejo, April 26, 1755, and the King, May 18, 1755, both in AGI, Panamá, 120. The case is mentioned briefly in Castillero Calvo, "Negros," p. 96 note 78.

96. The King, November 29, 1779, AGI, Panamá, 284

97. 1754-1756, AGI, Panamá, 155, N.1-N.7.

98. Castillero Calvo, “Color,” pp. 305-306; Bowser, “Colonial Spanish America," p. 48.

99. Ciriaco Hipolito Correoso, copy of baptismal certificate, December 16, 1773, AGI, Panamá, 283.

100. Likewise, Francisco Escartin, born in 1708, must have sent his petition for fiat to the King around his twenty-fifth birthday, as he had it denied in 1735, when he was 27 years old. Francisco Escartin to King, and resolution from the Consejo, September 1, 1735, AGI, Panamá, 152. 
ial office of Government and War, the most important such office in the Isthmus of Panama. ${ }^{101}$ Not only did Domingo agree to add his name to Ciriaco's record, but he declared in writing that he had always recognized Ciriaco as his son, publicly and privately, and had paid for his education. Furthermore, Domingo stated that he and Rosa Clavijo were both single and free to marry when Ciriaco was born. Although there is no evidence that they ever established a lasting relationship, Domingo's statement meant that Ciriaco was a natural son rather than the illegitimate offspring of an adulterous relationship. ${ }^{102}$ His father's recognition, together with references from well-connected people, ensured that Ciriaco obtained the fiat. He paid for a dispensation of color and later bought the notarial office of Government and War, where he worked until at least July 1808. ${ }^{103}$

In contrast, legitimacy was not an issue in Francisco de Arosemena's petition. Although he was the illegitimate son of a mulata and an 'unknown' father, he undertook an apprenticeship and by 1778 had obtained the fiat and was working as a notary. ${ }^{104}$ Nevertheless, legitimacy was taken into account in the Consejo's decision when two candidates of African descent competed for the same post. Gaspar de Aguilar, a quinterón living in Panama City, had been working in a notary office a few years before he decided to apply for the fiat, which was conceded to him in May 1755 along with the dispensation of color. ${ }^{105}$ In 1756, the office of public notary for the cabildo of Santiago de Veragua came vacant, and Aguilar decided to apply for it, as did another quinterón named Pedro Cayetano Escobar. As quinterones, both had the same defecto in the eyes of the governor and the cabildo, but Aguilar was the legitimate child of a legitimate marriage (as were both his parents) and Escobar was the natural son of a cuarterona. The local authorities decided to give the post to Aguilar, whose only barrier to office was a dispensation of color. ${ }^{106}$ When the case reached Spain for confirmation of the sale, controversy arose between the king and the governor, as the latter was not allowed to concede dispensations of

101. Certification of Francisco Nicolas de Aizpuru on November 10, 1768, as found in document of December 16, 1773, AGI, Panamá, 283.

102. See Twinam, Public Lives, pp. 36-41, 126-157. Scarlett O'Phelan Godoy resorts to the "Leyes de Toro," which considered illegitimate the child born or conceived when one or both parents were not free to marry. O’Phelan Godoy, "Entre el afecto y la mala conciencia. La paternidad responsable en el Perú Borbónico," in Mujeres, familia y sociedad en la Historia de América Latina, siglos XVIII-XXI, O'Phelan Godoy and Margarita Zegarra Flórez, eds. (Lima: CENDOC, Pontificia Universidad Católica del Perú, Instituto Riva-Agüero, Instituto Francés de Estudios Andinos, 2006), p. 38.

103. Consejo, November 25, 1778, AGI, Panamá, 283; and the King, November 29, 1779, AGI, Panamá, 284. For the 1808 reference, see Fidel Aguirre Medrano, Historia de los hospitales coloniales de Hispanoamérica, vol. 1 (Caracas: Editorial Arenas, 1992), pp. 352-362, doc. 10 (July 1808).

104. "Testimonio del expediente sobre dispensa de calidad," Viceroy of Santa Fé to King, March 31, 1778, AGI, Panamá, 284.

105. Consejo, May 21, 1755, and the King, June 22, 1755, both in AGI, Panamá, 120

106. Tello de Ugarte, "Panamá," p. 217 note 327. 
color. ${ }^{107}$ However, the post was later confirmed to Aguilar in 1760 and he was still working as notary of the cabildo in $1778 .{ }^{108}$ It could thus be that legitimacy was important only if its presence or absence were the key difference between applicants. On its own it does not seem to have been an issue.

This distinction appears to have applied also over generations of men of the same family who worked as notaries. As with other crafts, father-to-son and uncle-to-nephew transmission of the occupation-though not necessarily of a notarial office-was frequent. I have identified five families in which such transmission occurred: Avellaneda, Grillo, Gomez-Perez, Aizpuru and Borbua. ${ }^{109}$ Regarding the Avellanedas and Borbuas, the fathers' origins are unclear at this point. Both the Gomez-Perez and Aizpuru lineages began with out-of-wedlock births, but the men concerned managed to become notaries and to apprentice their descendants into notarial offices. In the Grillo family, the father (and first notary) was a natural son, but he and his descendants were later declared to have come from legitimate marriages, as has been related above.

The Gomez-Perez family spans the period from the 1680s until at least the 1750s and encompasses three generations. Miguel Perez, born in Portobelo to a mulata, petitioned for the fiat and notarial office and obtained them in 1692, paying for a dispensation of color. ${ }^{110}$ Although he was never accused of illegitimacy, his father is not mentioned in the sources; it is probable that the father provided for him without officially recognizing him. Miguel Perez married an unnamed woman who is nowhere referred to as having African ancestry in the sources, and they had several children. Two of them, Jorge Geronimo Perez and Juan de Dios Orencio Perez, followed in their father's footsteps and became notaries. Jorge Geronimo obtained the fiat in 1725, paying a dispensation for being pardo, and bought a notarial office in 1742. ${ }^{111}$ Juan de Dios worked as an official for a long time and did not

107. "Testimonio del expediente sobre dispensa de calidad," Viceroy of Santa Fé to King, March 31, 1778, AGI, Panamá, 284.

108. He was the notary of Santiago de Veragua's cabildo in 1764, 1770, and 1778. Torres Ramírez, Gil-Bermejo, and Vila Vilar, eds., Cartas de Cabildos, pp. 366-368, docs. 666-668. For confirmation of the fiat, see AGI, Panamá, 264, Book 3, fol. 247v.

109. For sixteenth-century white notaries in Santiago de Guatemala, Herrera has identified father-toson and uncle-to-nephew transmission of the notarial office, and argues that this was convenient not only for the family but also for the clients. He does not mention people of African descent working as notaries. Herrera, Natives, Europeans, and Africans, pp. 101-105. See also Burns, Into the Archive, pp. 83-93, for the relationships established over the years between notaries and individuals or convents. I thank Twinam for bringing to my attention Juan Evaristo de Jesus Borbua (personal communication, October 2013).

110. "Miguel Perez pide a Su Majestad que se le conceda el título de notario de las Indias," 1692, AGI, Panamá, 154, N.124a-ebis, fols. 529r-543v. For fee paid, see ibid., fol. 532r ("100 pesos aplicados"). See also AGI, Panamá, 101; and the actual royal decree confirming the concession of the dispensa and the amount paid ("100 pesos escudos de a diez de plata") in "Muy poderoso Señor, Miguel Perez . . .," AGI, Panamá, 154.

111. Consejo, November 14, 1736, and March 2, 1742, AGI, Panamá, 153; May 24, 1747, AGI, Panamá, 154; four "Testimonio de los Autos" in the case of Jorge Geronimo Perez, 1750s, AGI, Panamá, 154. 
obtain the fiat, or the dispensa de pardo, until 1749. ${ }^{112}$ This process may not have been as difficult, as he was the fourth member of the family to obtain it, after his nephew Eusebio Joseph. ${ }^{113}$

Eusebio Joseph Gomez, born in 1720, was the son of Josefa, the daughter of Miguel Perez, and of Bernardo Gomez, a silversmith who was not of African descent. ${ }^{114}$ When he petitioned to become a notary in 1744 , he presented his grandfather's and uncle's titles as supporting documents, which demonstrates that family precedents helped when presenting the petitions. Eusebio Joseph obtained the fiat and notarial office in 1747, paying the dispensation of color for being pardo. ${ }^{115}$ Eusebio Joseph's brother, Bernardo Joseph Gomez, was receptor in the late 1750 s, a notarial position that required confirmation by the Consejo and king. I have not located the record of confirmation or learned whether he paid for obtaining the dispensa. ${ }^{116}$ The Gomez-Perez family case demonstrates that the notarial occupation was transmitted through both paternal and maternal lines. It also shows that the profession provided enough wealth to allow three generations in succession to pay what was needed to meet the requirements, and that the family was well-respected and sought out for favorable marriages-Josefa's husband was the master silversmith of Panama City.

The second genealogy presented for discussion, a remarkable one, is that of the Aizpuru family. They may, or may not, have been of African descent and were identified as of illegitimate origin. The analysis of this family enlightens us as to the aspirations of some notaries of color and their place in colonial society. Captain Juan de Aizpuru was a wealthy white man, a respected public figure, who held the office of alcalde ordinario of Panama City on three occasions. He had a natural son, Juan Ignacio de Aizpuru, with a woman named Francisca, whose ancestry was disputed at the time. Captain Aizpuru publicly recognized and raised Juan Ignacio as his son in Portobelo, probably on his own, and gave him 3,000 pesos in adulthood, an amount that allowed him to bid for the Government and War notarial office. He presented himself as a candidate in 1713,

112. Consejo, February 8, 1749, and the King, March 14, 1749, AGI, Panamá, 120.

113. "Año de 1760," fol. 53v, and Raymundo and Gabriel Gomez to Governor Montiano, December 1754(?), Archivo Histórico Nacional, Madrid, Consejos, 20627 [hereafter AHNM-C-20627].

114. Copy of baptismal certificate of Antonio de la Serna, May 24, 1747, AGI, Panamá, 154. Consulting the same source, Ángeles Ramos Baquero proposes that Miguel Perez and Jorge Geronimo were Eusebio's great-grandparents. Pérez Calderón understands, as I do, that they were his grandfather and uncle respectively. Neither of these authors mentions Juan de Dios Orencio Perez. Ángeles Ramos Baquero, "Platería y plateros en el arte colonial," in Historia General de Panamá, Alfredo Castillero Calvo, ed., vol. I-II, p. 280; Pérez Calderón, "Política," p. 272.

115. Consejo, May 6, 1747, and the King, June 12, 1747, AGI, Panamá, 120.

116. Puyo to Viceroy Solís (undated, c. 1756-1759), “Año de 1760," fol. 83v, copy of July 7, 1759, AHNM-C-20627. 
and held the post of notary of Government and War until 1738. ${ }^{117}$ Don Juan Ignacio was also notary of the cabildo from at least 1716, and the institution reported twice on his good performance in the 1730s, asking that he be confirmed in the post. ${ }^{118}$ Don Juan Ignacio was socially well connected and married doña Francisca Montero, a white woman. However, while married to her, he had a son with her sister, doña Petra Montero, whom he married immediately after his first wife died. ${ }^{119}$ This son, Francisco Nicolas de Aizpuru, was trained as a notary and petitioned for and obtained the fiat in $1734 .{ }^{120}$ Don Juan Ignacio resigned and handed over to him the post of Government and War notary in 1738, although Francisco Nicolas did not come to own it until 1742. ${ }^{121} \mathrm{He}$ held that position until 1779 and at some point also obtained the notarial office that had belonged to Joseph de Avellaneda (senior). ${ }^{122}$ Francisco Nicolas de Aizpuru married and had five children, and his salary allowed him to maintain his children and support his spinster sisters throughout his life. ${ }^{123}$

Francisco Nicolas's successful career was endangered by accusations that he was of both African descent and illegitimate birth. He was anonymously accused of having obtained the notarial office of Government and War without declaring that he was of African descent (the informants argued that his father had obtained a dispensation of color, but I have not found evidence of this), and of having obtained the post thanks to the support of two oidores from the audiencia. ${ }^{124}$ Francisco Nicolas and his relatives defended themselves, declaring that he was blanco and had pure origins - as had his parents, grandfather, sisters, wife and children-and was everywhere addressed as 'don.' 125 The focus of the accusation was his grandmother, Francisca, whom Captain Aizpuru

117. For 1713: Fray Pedro Franco de Ynostrosa declaring in favor of Juan Ignacio de Aizpuru, November 23, 1713, AGI, Panamá, 152. For 1777: Francisco Nicolas de Aizpuru to the governor, February 13, 1777, AGI, Panamá, 284.

118. I do not know if his post was ever confirmed. Torres Ramírez, Gil-Bermejo and Vila Vilar, eds., Cartas de cabildos, p. 165 doc. 313 (year 1716); p. 182 doc. 344 (year 1730); p. 183 doc. 346 (year 1731).

119. "Testimonio de la causa criminal que se sigue ... contra Francisco Nicolas de Aizpuru," September 17, 1746, AGI, Panamá, 137.

120. Juan Ignacio Aizpuru to the King, 1735, AGI, Panamá, 152.

121. For the confirmation of the fiat and notarial office, see the King, December 23, 1742, AGI, "Panamá," 119; and "Expediente sobre la confirmacion despachada en el año de 1742 a Don Francisco Nicolas de Aizpuru del oficio de escrivano de camara de la audiencia de Panama," 1742, AGI, Panamá, 153.

122. In 1768 he acted as witness and presented himself as owner of both posts. Francisco Nicolas Aizpuru, December 16, 1777, AGI, Panamá, 283.

123. By 1777 his income had decreased with economic downturn in the Isthmus. In addition, he had not been paid for the services provided to the militia, and he complained that he could not provide for the maintenance of his extended family. Francisco Nicolas de Aizpuru to the governor of Panama, February 13, 1777, AGI, Panamá, 284.

124. "Informacion a V. M. con la Acusacion anonima contra la familia de los Aizpuru," June 16, 1754, and on a bitter dispute between notary Albear and Aizpuru, in which the latter was accused of being mulato, between 1751-1755, AGI, Panamá, 155. The two oidores were Juan Perez García and Juan Bautista Bahamonde. Report by the governor, September 29, 1746, AGI, Panamá, 137.

125. On passing and public and private recognition, see Twinam, Public Lives, pp. 140-157. 
never married. Who was she? ${ }^{126}$ And why did members of the same family seem not to agree on an answer?

On his marriage certificate, Juan Ignacio stated that his mother's name was Francisca Baves, without the 'doña,' and did not specify if she was a Spaniard or not. When Francisco Nicolas defended himself against the accusations mentioned above, he stated that his grandmother was doña Francisca de Arazo, a respected and well-known Spaniard who lived in Cartagena. Back in 1713, a witness had given testimony that Juan Ignacio was born in Cartagena and was the natural son of Captain Juan de Aizpuru and the Spaniard doña Francisca de Arazo, and that he had been taken to Portobelo by his father. ${ }^{127}$ Those who accused Francisco of having African ancestors argued that his grandmother was a freed woman named Francisca de Chaves who lived in Portobelo. Although it is not possible at this stage to know which of these versions is true, it is evident that something was being hidden since Juan Ignacio and Francisco Nicolas did not give the same details for Francisca. Further, Francisco Nicolas specifically mentioned his grandfather, but not his grandmother, when stating that his family was white. Francisco Nicolas was also accused of illegitimacy, because at the time of his conception and birth his father was married to his aunt. The fact that his parents later married facilitated public acceptance of the adulterous relationship, but his out-of-wedlock birth to an adulterous man remained in the memory of his contemporaries. Despite all these accusations, Francisco Nicolas successfully defended his case throughout the 1750s and continued to occupy the most important notarial office of Panama until he handed it over in 1778. Further evidence of his success is that two siblings and notaries with the family name Aizpuru, Josef Patricio de Aizpuru and Juan Ignacio de Aizpuru, were active in the 1780s; the former handed over to the latter a notarial office in $1786 .{ }^{128}$ I suggest that they may have been Francisco Nicolas' offspring.

The two eldest Aizpuru notaries were addressed as 'don'’ a title traditionally assigned only to Spaniards or others of European descent who were reputed to be honorable and respectable people of elevated socioeconomic status. This raises the question of why the two Aizpurus would want to pass as whites or to claim Spanish descent, if other notaries of color were successful without such pretensions. To what degree were notaries of African descent respected and integrated into Panama City's bureaucracy and its social milieu? Further

126. For the primary sources of the discussion on Francisca, see Don Francisco Nicolas de Aizpuru, escribano de Gobierno, 1753-1755, AGI, "Panamá," 155; and "Testimonio de la causa criminal que sigue," September 1746, AGI, Panamá, 137.

127. Fray Pedro Franco de Ynostrosa, November 23, 1713, AGI, Panamá, 152.

128. AGI, Panamá, 254, document listing notaries in Panama City, March 4, 1786. 
research on the Aizpurus has uncovered some of their social network, which leads to an understanding of how social relations worked in their circle. Francisco Nicolas Aizpuru's life shows daily interaction between men of European and African descent within the notarial offices. Francisco Nicolas had in his office premises white and colored apprentices and oficiales, and promoted them to obtain different notarial offices. Whether or not he was of African descent, he was willing to work with all in his office, which suggests that his desire to prove exclusive European descent did not affect his professional relationships or his attitude toward some people of mixed ancestry in Panama. One of his sisters, Ana Aizpuru, was married to the white notary Joseph Bermudez, and Francisco Nicolas handed over two of his notarial offices to two notaries of color in 1778. The War and Government notarial office was handed over to Ciriaco Hipolito Correoso, as discussed above, and the Renta del Tabaco office to Miguel Santiago del Cid (or Sid). Del Cid, the son of a mulata, was granted the fiat and paid for the notarial office and the dispensation of color. ${ }^{129} \mathrm{How}^{-}$ ever, he died just a year later, and the notarial office was bought by don Francisco Cueto de Guzman, a white man. ${ }^{130}$

Notarial offices were sold or handed over to the best available notary or to the one who could pay for it, independently of their ancestry or calidad. Notaries of color worked alongside white and all were apprenticed together, which also suggests a degree of mutual acceptance and recognition, even though there were bitter arguments and appeals when they had conflicting interests over the ownership of a specific notarial office. Paramount in establishing their place in society was not so much their ancestry as their training, education, social and professional networks, and professionalism.

\section{The Path to the Gracias al Sacar}

While the Aizpurus may have tried to disguise their ancestry through confusing statements regarding their mother or grandmother, the other notaries typically did not do so. Only in the second half of the eighteenth century, one encounters two notaries of African descent who did try to change their public status, in two different ways. The first was Carlos Santos de la Peña, who asked the crown to change his illegitimate birth status in 1749, and was granted his request in 1761 . Although $\mathrm{I}$ have not found documentation that Santos de la Peña was addressed as 'don,' Twinam has located documents in which he is,

129. "Testimonio del expediente sobre dispensa de calidad ..., "Viceroy of Santa Fé to the King, March 31, 1778, AGI, Panamá, 284. Confirmation of notarial office in 1778: "Inventario de minutas de despachos desde 1760-1781,” fol. 286v, AGI, Panamá, 246.

130. The King, November 29, 1779, AGI, Panamá, 284. 
which led her to argue that he had passed "both socially and racially."131 However, his career path suggests he had not passed racially. He was first based in Portobelo and moved to Panama City in the 1750s, where he requested the fiat circa 1760 and with it a dispensation of color, which clearly shows that he had not already 'passed'. He obtained it in 1761 and was still working in 1774. ${ }^{132}$ Santos de la Peña may have been an early example, along with Aizpuru, of some notaries of color who considered it worth the administrative procedure to have their public status changed, despite local precedents.

About 50 years later, in 1803, Mathias Joseph Borbua, a notary working as second assistant, applied for the dispensation of the calidad de pardo so that he could thenceforth be "reputed and regarded as a persona blanca." The file includes a list of prices for the gracias al sacar, and his case is the first I have located of a notary of color asking for the obliteration of his African ancestry. ${ }^{133}$ Borbua's baptismal certificate provided no evidence of African origins but did certify his legitimate birth. Borbua argued that although he was pardo, this was not evident in his behavior, occupation, and reputation, or on his birth certificate, which means that the family had generally been considered to be white. However, his father was the notary Juan Evaristo de Jesus Borbua, whom Twinam has identified as a quinterón who applied for the fiat in 1767 and obtained it, paying for the dispensa de color. ${ }^{134}$ Despite this family background, the Cámara's response at the time was to dismiss the petition (" no ha lugar"), although he might have been successful later on. ${ }^{135}$

This last case suggests that the institution of gracias al sacar fees in 1795 did have an impact on the hopes of some men of color who were training as notaries in Panama. For decades it had been sufficient that local aspirants ask (and sometimes pay) for the dispensation of color. However, Mathias Joseph Barbua applied for the dispensation of color within the framework of the gracias al sacar, asking not for a dispensation of color, but that he thenceforth be considered white. It seems doubtful that the institution of the gracias al sacar implied a sharp change of opinion and public regard. The War and Government notary, Ciriaco Hipolito Correoso, did not feel the need to ask for it and was still working actively when Napoleon precipitated the events that would lead to the end of the Spanish dominance of most of its American territories.

131. On the request to erase Santos de la Peña's illegitimate birth, see Twinam, Public Lives, pp. 259260. The quoted lines are from p. 260. The identification between the two seems clear.

132. Confirmation of fiat "Inventario de minutas de despachos desde1760-1781," fols. 249v and 251r, AGI, Panamá, 246. On 1774, see Tello de Ugarte, "Panamá," p. 217 note 327, and p. 82 note 111.

133. 1803, AGI, Panamá, 293, exp. 3.

134. Twinam, forthcoming, cites AGI, Panamá, 276, N.3, 1767.

135. Twinam did not discuss this case in Public Lives. 


\section{CONCLUSION}

There is no doubt that the legislation issued by the monarchs and the administrative decisions made by the Consejo de Indias throughout the earlymodern period identified people of African descent and of illegitimate birth as inferior imperial subjects who were banned from many occupations, including notarial office. Nevertheless, the research presented in this article demonstrates that from the early seventeenth century, if not before, the metropolitan authorities' actual practice went against their own law: it conceded fiats and notarial offices to men of color in Panama in exchange for their obtaining dispensations of color, and very frequently did not regard out-of-wedlock birth as a major impediment. The implications of this practice across centuries, economic contexts, and cases are multiple.

Legal flexibility within the Spanish empire was a recognized component of governance, and exceptions, gracias, and tergiversations of the law were frequent when appealing a sentence. To address why the monarchs and the Consejo de Indias might have adopted this flexible practice with the notaries of color, at least two propositions can be put forward. First, the seeking of notarial office can be seen as a way in which free people of color challenged the limits imposed on them, resorting to the existing Spanish tradition of issuing dispensations. This interpretation emphasizes the agency of imperial subjects, and the ways in which their resistance and knowledge and their strategies for using imperial legislation changed policies and practices from below, across the Spanish empire. On the other hand, the monarchs and Consejo members were very conscious of the internal and external challenges they faced in running the empire. Adopting an unofficial practice that eased the way for some prosperous, fair-skinned, and well-trained men of African descent would generate friends rather than enemies. Flexibility was the norm in Spanish law, and it was not until the late Bourbon reforms that some uniformity in legislation was attempted. While it is true that the empire sought to collect revenue from fiats and dispensas and other such documents, I suggest that the consideration of these two propositions can lead to a more comprehensive analysis of the dynamics of the Spanish empire.

Prosopographical analysis is enlightening in many ways, especially in its consideration of limpieza de sangre and legitimacy as core values for understanding early modern Spanish-American society. That notarial aspirants had only to declare their African ancestry, and would only in later periods have to pay an extra fee to have it disregarded, illustrates that official routes to upward socioeconomic mobility and social and political acceptance-both locally and at imperial level (the monarchs and the Cámara) -were in place well before the 
1790s. Limpieza de sangre and calidad were relatively less important for some administrative positions, mainly when precedents existed and the individual aspirants were well connected, relatively wealthy, trained to the work, and educated. Notaries of color in Panama, as well as in cities of other Spanish American lands, knew they could be successful in their aspirations to become notaries without pretending to pass as whites or disguise their birth circumstances. In seeking notarial and other official positions, they counted on recognition of the other aspects that shaped an individual's calidad, identity, and place in colonial Spanish America: behavior, morality, wealth, social networks, education, public image, and other factors. To be sure, none of the individuals discussed here were described as 'blacks.' All were free (not freed), all participated in economic and social support networks, and all were cuarterón, quinterón or (more generically) pardo. ${ }^{136}$ However, the notarial aspirants' embrace of the elements of calidad was constructed to comply with what was expected of a notary and did not constitute an effort toward substantively changing their calidad. Ben Vinson III has argued that "color status became safer to claim" in the corporate militias of colonial Mexico, because the participation of colored militiamen brought them socioeconomic improvement and recognition. ${ }^{137}$ In a parallel manner, and with the difference that Mexican militiamen were already members of the militia, I argue that men of color living in Panama found themselves in a position and context in which, generally, they could achieve a public office without hiding their African ancestry.

The issue of legitimacy also runs through the discussion, and serves to highlight some aspects of interracial relationships and marriage among Panama's residents, particularly the families into which future notaries were born. On many occasions, the father was blanco or español and the mother either mulata or cuarterona, and their relationship was an informal one. These relationships bring to light free, economically self-sufficient women of color who were heads of households in Panama, who established relationships with reputable and frequently wealthy white men with whom they had children. These men in the main took responsibility and cared for their offspring. Even though they did not always recognize their children publicly, they managed to place their sons as apprentices in notarial offices. This tendency was reversed in the second generation within families of notaries, as with Francisco Nicolas Aizpuru, Silvestre Botacio Grillo, and the Gomez-Perez family, when the person of African descent was the father (who was also the notary) and the mother was a white woman. This indicates that some of these men probably lived a comfortable

136. Pardo is frequently used on its own in documentation but also as alternative adjective word in place of cuarterón or quinterón, although I do not mean that they were synonyms.

137. Ben Vinson III, Bearing Arms, chapt. 3 and pp. 226-227. 
life. They were accepted into the moderately well-off socioeconomic circles of society and married white women, who probably accepted them on the basis of their occupation and social standing, or-why not?-out of love. ${ }^{138}$ This social context could suggest the existence in Panama of a small free elite of African descent. Studies of other parts of the early modern Americas, such as those of Vinson in Mexico, King in Saint-Domingue, Hanger in New Orleans, and Bowser in Peru, show that a fair-skinned, well-connected group of free African descendants who could count on supportive socioeconomic networks (family, godparents, patronage) and held certain occupations were more likely to succeed than other free people of color. ${ }^{139}$ The role of these lettered men of African descent in the independence period and the new republic is a theme for further research, as is the nature of the social relations that notaries of color established with other sectors of Panamanian society.

There is no doubt that the dispensas de color should be understood as a precedent of the gracias al sacar decrees of the late eighteenth century. Several notaries discussed in this article were required to pay fees for their dispensa de color. For instance, in mid seventeenth- century Lima some notaries had paid the fee, all members of the Gomez-Perez family had done so since 1692, Ciriaco Hipolito Correoso complied in 1778, and Juan Lopez de Motos had to pay for a dispensa in 1670 when his right to work as a notary was questioned. However, there are other cases in which no payment was made, and the existence of a payment did not mean that subsequent petitions and gracias would be granted, or that fees would be paid for them. Also, it seems that the amount demanded in payment was not constant. It would become so only later, when the fee was calculated for the gracias al sacar.

Another difference between the dispensa and the gracias al sacar is that the former did not erase African ancestry. Rather, it acknowledged it and provided mixed-race notarial aspirants with the potential for public recognition of their skills and knowledge and an improved socioeconomic status. In contrast, the gracias al sacar officially deleted an unwanted characteristic (African ancestry and illegitimacy, among others) so that the grantee would lose that characteristic in any legal sense and thenceforth be considered white, legitimate, or

138. In only one instance did I find evidence that a notary of African descent chose to marry a woman of color. He was Miguel Angel de Rivas, natural son of a mulata and an unknown father, who worked in the cabildo of Santiago del Alanje in Panama. In 1766 there were complaints about his lack of ability as notary. “Testimonio del expediente sobre dispensa de calidad," May 31, 1778, AGI, Panamá, 284.

139. Vinson, Bearing Arms; Douglas Cope, Limits of Racial Domination: Plebeian Society in Colonial Mexico City (Madison: University of Wisconsin Press, 1994), chapt. 3, especially pp. 49-57; Stewart R. King, Blue Coat or Powdered Wig: Free People of Color in Pre-Revolutionary Saint Domingue (Athens and London: University of Georgia Press, 2001); Kimberly Hanger, Bounded Lives, Bounded Places: Free Black Society in Colonial New Orleans, 1769-1803 (Durham and London: Duke University Press, 1997). 
defined by some similarly acceptable quality. This was no guarantee, however, that the individual's status in the community would change or that their defecto would be disregarded in other contexts. ${ }^{140}$ It is unclear what changes in status might have prompted the institution of the gracias al sacar, but they do not seem to have been radical ones. Only one notary out of several working at the time asked for a gracias al sacar.

University of St. Andrews

Silvia Espelt-Bombín

Fife, Scotland

140. Twinam, "Purchasing Whiteness: Conversations on the Essence of Pardo-ness and Mulatto-ness at the End of the Empire," in Imperial Subjects, p. 160. 